\title{
Avvägningen mellan yttrandefriheten och skyddet för privatliv i EMD:s praxis - lotteri eller enhetlig verksamhet? $^{1}$
}

\author{
Af Päivi Tiilikka ${ }^{2}$
}

\section{Abstract}

This article examines the praxis of the European Court of Human Rights (ECrtHR) when balancing the protection of privacy and freedom of expression. As the ECrtHR has constantly stated, the freedom of expression, as guaranteed in the ECHR Article 10, constitutes one of the essential foundations of a democratic society and one of the basic conditions for its progress and for each individual's self-fulfillment. The concept of private life, as guaranteed by the ECHR, Article 8, is a broad term, which covers the physical and psychological integrity of the person. It also covers the protection of reputation and honor, as well as the right to personal information - which individuals can legitimately expect should not be published without their consent. This article discusses the protection of privacy only in the latter sense.

The text describes and analyzes the ECrtHR's case law regarding the balancing of freedom of expression and the right to privacy. Until the early $2000 \mathrm{~s}$, the protection of private life was considered an acceptable limitation on the freedom of expression. However, in the current court practice, the right to privacy is considered as an equivalent right to freedom of speech. This has made the weighting and balancing between the protection of privacy and freedom of expression a more difficult task both in the national courts and in the ECHR.

The article examines the key criteria which are important when balancing the freedom of expression and the protection of private life, namely: the ECrtHR's general interpretation principles; the margin of appreciation; contribution to a debate of general interest; the public role of the person concerned; the subject of the news reporting; how information is obtained and verified; the content, form and consequences of the publication; the special characteristics of photography; and the proportionality of the sanctions imposed.

The writer concludes that the application of the aforementioned criteria has not always been consistent. If the ECrtHR's court practice is too inconsistent it can jeopardize the legal certainty and reduce the intelligibility and prestige of the ECHR's praxis. At the same time it is increasingly difficult for the national courts 
to implement the praxis of the ECrtHR to the national jurisdiction. If the praxis of the European Court of Human Rights appears to be too contradictory or confusing it can undermine the respect of its judgments and lead to diminishing rebuke of its condemnatory judgments.

\section{Inledning}

\subsection{Artikelns syfte}

I denna artikel granskar jag för det första hur skyddet för privatliv - vilket ska förstås som rätten att hålla vissa saker enbart för sig själv eller sin närmaste krets - i Europeiska människorättsdomstolens (EMD) praxis har förstärkts och utvecklats från en tillåten inskränkningsgrund i enlighet med artikel 10(2) i Europeiska människorättskonventionen (EMRK) till att skyddas av artikel 8 EMRK i form av ett rättsgott jämställt med yttrandefriheten. Till detta anknyter även statens skyldighet att trygga skyddet för privatliv genom exempelvis straff- och skadeståndslagstiftning. ${ }^{3}$ Skyddet för privatliv granskas uttryckligen med avseende på sanningsenlig, men till privatlivets sfär hörande, information. Skyddet för ära och rykte - trots att även dessa faller inom området för skyddet för privat- och familjeliv enligt artikel 8 EMRK - granskas här inte i övrigt än som åskådliggörande jämförelser. För det andra analyserar jag de bedömningskriterier som EMD efterföljt vid sin avvägning och deras tillämpning. Ytterligare bedömer jag EMD:s avgörandepraxis framför allt med tanke på rättssäkerheten och förutsebarheten.

\subsection{Yttrandefriheten och inskränkningen av den}

Yttrandefriheten tryggas i artikel 10 EMRK. Enligt den har var och en rätt till yttrandefrihet. Yttrandefriheten innefattar åsiktsfrihet samt frihet att ta emot och sprida uppgifter och tankar utan offentlig myndighets inblandning och oberoende av territoriella gränser. Enligt EMD:s tolkning ska stater avhålla sig från att kränka yttrandefriheten, men därutöver vid behov även vidta aktiva åtgärder $\mathrm{i}$ syfte att trygga yttrandefriheten. ${ }^{4}$

Artikel 10(2) EMRK möjliggör inskränkningar av yttrandefriheten med hänsyn till den nationella säkerheten, den territoriella integriteten eller den allmänna säkerheten, till förebyggande av oordning eller brott, till skydd för hälsa eller moral, till skydd för annans goda namn och rykte eller rättigheter, för att förhindra att förtroliga underrättelser sprids eller för att upprätthålla domstolarnas auktoritet

* Title in English: Balancing the freedom of expression and protection of private life at ECrtHR's praxis: A lottery or coherent activity? 
och opartiskhet. Inskränkningen skall vara föreskriven i lag och vara nödvändig i ett demokratiskt samhälle.

Kravet på att inskränkningen ska vara föreskriven i lag förutsätter att inskränkning har sin grund i den statsinterna rätten, att normen är tillgänglig och att tolkningen av den är förutsebar i tillräcklig mån. Experter på området förutsätts kunna tolka förhållandevis komplicerade normer. Kravet på inskränkningsbestämmelsens förutsebarhet uppfylls om en person på förhand - vid behov med hjälp av juridiska råd och rättspraxis - kan erhålla tillräcklig säkerhet om risken för straffpåföljd och ersättningsansvar i förhållande till hans eller hennes gärning. I rättslitteraturen har man ansett att EMD alltför lättvindigt betraktat kravet på att inskränkningen ska vara föreskriven i lag vara uppfyllt, med beaktande av att obestämda lagar har en hämmande verkan på utövningen av yttrandefrihet. ${ }^{5}$

Vid bedömningen av kränkningar av yttrandefriheten har inskränkningens nödvändighetsbedömning ofta spelat en avgörande roll. Denna granskning har EMD gjort i ljuset av tre kriterier:

- grundar sig inskränkningen på ett trängande socialt behov?

- står inskränkningen i rätt proportion till ett godtagbart syfte?

- är de skäl för inskränkningen som framförts av den nationella myndigheten relevanta och tillräckliga? ${ }^{6}$

Faktorer som ska beaktas vid nödvändighetsbedömningen är bl.a. publikationsforumet, den publicerade informationens anknytning till en debatt av allmänt intresse, meddelandeuppgivarens roll, meddelandets objekt och dennes egen offentliga eller allmänt betydelsefulla verksamhet, meddelandets sanningshalt, övrig debatt som förts kring temat samt eventuell publicering av bemötande eller korrigering, huruvida temat redan tidigare behandlats i offentligheten, huruvida det handlar om skriftlig information eller ett fotografi, hur enkelt meddelandets objekt kan identifieras och huruvida journalisten agerat $\mathrm{i}$ god tro i enlighet med god pressetik. Av betydelse är även kvaliteten och kvantiteten av de påföljder som påförts för nyttjandet av yttrandefriheten. Dessa kriterier granskas mera detaljerat senare i denna artikel.

\subsection{Yttrandefriheten och skyddet för privatliv $i$ de nordiska länderna}

I slutet av år 2011 har EMD gett 16 domar där den ansett att Finland kränkt yttrandefriheten såsom den tryggas i artikel 10 EMRK. I nio av dessa fall var de fråga om avvägningen mellan yttrandefrihet och skydd för privatliv, medan de övriga fallen hänförde sig till avvägningen mellan yttrandefrihet och skydd för 
ära. Vid samma tidpunkt har EMD ansett att Norge kränkt yttrandefriheten fem gånger, Sverige två gånger och Danmark en gång. Av de norska domarna hänförde sig två till skyddet för privatliv, fastän den ena domen handlade om skyddet för ära som en del av skyddet för privatliv. I bägge svenska domar var det fråga om skyddet för privatliv, men i den ena hänförde sig den rättsliga frågan inte till publiceringen av information och i den andra var det fråga om skyddet för ära såsom en del av skyddet för privatliv enligt artikel 8 EMRK. I det danska målet var det fråga om rasistiska uttalanden. Ytterligare har yttrandefriheten vägts mot skyddet för privatliv i några mål som berört de nordiska länderna, där någon kränkning inte konstaterats.

I Finland, Norge och Danmark finns uttryckliga strafflagsbestämmelser som kriminaliserar spridande av information som kränker privatlivet. I Finland föreskrivs om skyddet för privatliv i 24 kap. 8 § (531/2000) i strafflagen, enligt vilken det är fråga om spridande av information som kränker privatlivet då någon obehörigen 1) genom ett massmedium eller 2) genom att på något annat sätt göra tillgängligt för ett stort antal människor framför en uppgift, antydan eller bild som gäller någons privatliv så att gärningen är ägnad att orsaka skada eller lidande för den kränkte eller utsätta honom eller henne för missaktning. Bestämmelsens andra moment möjliggör övervakningen av maktutövare. Enligt andra momentet anses som spridande av information som kränker privatlivet inte »framförande av en uppgift, antydan eller bild som gäller en sådan persons privatliv som verkar inom politiken, näringslivet, i en offentlig tjänst eller i ett offentligt uppdrag eller i något annat med dessa jämförbart uppdrag, om uppgiften, antydan eller bilden kan påverka bedömningen av personens förfarande i nämnda uppdrag och framförandet behövs för behandlingen av någon samhälleligt betydelsefull sak«. I rättspraxis har exempelvis familjeliv, hälsotillstånd, människorelationer och sexualliv omfattats av sfären för privatliv. Frågan om skyddet av t.ex. gärningsmäns namn och bilder har varit oklar. ${ }^{8}$

I Norge skyddas privatlivet i strafflagens (Almindelig borgerlig Straffelov) $390 \S$, enligt vilken den som kränker privatlivets fred genom att framföra ett offentligt meddelande om personliga eller hemförhållanden straffas med böter eller fängelse upp till 3 månader. ${ }^{9}$ Uttolkningen av personliga förhållanden har varit tämligen bred. Sådana förhållanden har ansett omfatta förhållanden till närstående, information om politiska och religiösa övertygelser samt medicinska och sexuella omständigheter och i viss omfattning även ekonomiska omständigheter. Bestämmelsen gäller både sanningsenliga och osanna påståenden..$^{10}$ Ytterligare har personer rätt till sin egen bild enligt $45 \mathrm{c} \S$ i upphovsrättslagen (Lov om opphavsrett til åndsverk). Fotografering regleras även i 131 a § i domstolslagen (Lov 
om domstolene). Enligt Eggen är upphovsrättslagens bestämmelse om fotograferingsförbud problematisk med tanke på yttrandefriheten, eftersom den även omfattar andra bilder än ömtåliga sådana som hör till sfären privatlivet. ${ }^{11}$

Enligt $264 \mathrm{~d}$ § i Danmarks strafflag (straffelov) straffas den med böter eller fängelse i högst 6 månader som oberättigat sprider meddelanden eller bilder rörande en annans privata förhållanden eller bilder av en annan under sådana förhållanden, där dessa uppenbart inte är ämnade att komma till offentlig kännedom. Bestämmelsen gäller även för meddelanden eller bilder avseende en avliden person. I rättspraxis har privata förhållanden ansetts omfatta t.ex. interna familjeangelägenheter, information om sexuella förhållanden, skilsmässor, sjukdomar, privata tvister, självmord eller försök till sådana. Även privata föreningars eller samfunds interna angelägenheter kan höra till området för privata förhållanden. Liksom i Finland och Norge beror straffbarheten inte på meddelandets sanningsenlighet. Gärningens rättmätighet kan grunda sig på upplysningsplikt, allmänt eller enskilt intresse eller samtycke. $^{12}$

Spridande av information som kränker privatlivet har inte kriminaliserats i Sverige. I vissa fall kan spridande av information som gäller privatlivet vara straffbart i form av ärekränkning, eftersom grundformen av ärekränkning inte förutsätter att informationen vore osann, utan kan uppfyllas även vid spridande av sanningsenlig information. Skydd kan även erhållas genom lagstiftningen om behandling av personuppgifter. ${ }^{13}$ Man har länge överlagt ett bättre skyddande av privatlivet, men ärendets framskridande har varit trögt. ${ }^{14}$ Enligt den år 2004 tillsatta integritetsskyddskommittén (Integritetsskyddskommitén, SOU 2008:3) har lagstiftaren inte lagt tillräckligt mycket vikt vid synpunkter gällande integritetsskyddet. Istället för skapandet av en helhetsbild har man erbjudit skydd i enskilda fall och punktuellt. Även i delbetänkandet SOU 2007:22 om skyddet för den personliga integriteten ansåg man att respekten för privatlivet är svagt i masskommunikationen och på Internet. ${ }^{15}$ Även kommittén som utredde en eventuell revidering av tryckfrihetsförordningen och yttrandefrihetsgrundlagen (SOU 2006:96, Del I) konstaterade att skyddet för privatliv är svagare i Sverige än i många andra EU-länder och att skyddet av yttrandefriheten på motsvarande sätt är starkare än annorstädes. Kommittén talar även om en svensk offentlighetsprincip.

På basis av det ovan anförda påminner Finlands, Norges och Danmarks kriminaliseringar angående skyddet för privatliv om varandra - även om Norges och Danmarks bestämmelser inte innehåller en liknande uttrycklig begränsning av straffansvarets område vid bedömningen av maktutövares verksamhet som den finska bestämmelsen i SL 24:8.2. Samma slutresultat kan dock erhållas genom tolkning. Såväl i Finland, Norge, Danmark som Sverige ges en stor tolkningsef- 
fekt åt EMD:s avgörandepraxis vid avgörande av yttrandefrihetsmål, alltså kan straffbarhetsområdet begränsas även härigenom.

\section{Yttrandefriheten som en grundpelare i det demokratiska samhället}

EMD:s avgörandepraxis har traditionellt varit mycket yttrandefrihetsbejakande. Enligt EMD utgör yttrandefriheten en av grundpelarna i det demokratiska samhället och en förutsättning för samhällets utveckling. Yttrandefriheten har även en viktig betydelse för varje individs möjligheter att förverkliga sig själv. Yttrandefriheten gäller även för stötande, chockerande och upprörande information och idéer, eftersom ett demokratiskt samhälle förutsätter pluralism, tolerans och vidsynthet. $^{16}$

EMD har understrukit pressens funktion som »offentlig vakthund « och dess rätt att sprida uppgifter och åsikter. EMD har även betonat allmänhetens rätt att få motta dessa. Trots att pressen inte făr överskrida bl.a. vissa specifika gränser som utsatts i syfte att skydda andras rykte och rättigheter samt förhindra spridandet av konfidentiell information, skall den ändå med beaktande av sina förpliktelser och sitt ansvar förmedla information och tankar kring alla ämnen av allmänt intresse. Inskränkningar av yttrandefriheten ska tolkas snävt och det måste föreligga övertygande bevis om deras nödvändighet. ${ }^{17}$

I exempelvis fallet Bergens Tidende m.fl. mot Norge (2.5.2000 § 52), som handlade om tidningsskriverier som berättade om komplikationer och andra men som orsakats plastikoperationspatienter och kritiserade en viss kirurg, konstaterade EMD att såvida de nationella myndigheternas åtgärder kan försvaga pressens dristighet att sprida information om ämnen som väcker allmän oro, måste proportionaliteten av de inskränkande åtgärderna övervägas särskilt noggrant. I fallet hade ett tidningsbolag samt journalisterna dömts att betala skadestånd på nästan fem miljoner respektive knappa 45000 kronor till följd av den ekonomiska skada som orsakats av tidningsskriverierna.

EMD har i åtskilliga av sina domar konstaterat att artikel 10 EMRK, med de begränsningar som nämns i 2 punkten, utöver positiv, ofarlig eller likgiltig information även är tillämplig på stötande, upprörande och oroväckande sådan. Pressfriheten innefattar även möjligheten att ty sig till viss överdrift och provokation. ${ }^{18}$ Denna rätt omfattar dock inte publiceringen av fullständigt ogrundad information. I t.ex. fallet Abeberry mot Frankrike (21.9.2004, beslut) konstaterade EMD att med beaktande av allvaret av de ogrundade påståendena (som gällde en polis deltagande i en terrororganisation samt tagande av mutor) och publikationens stötande ton, var det inte fråga om en sådan överdrift eller provokation som vore tillåten i samband med pressfriheten. Såsom EMD konstaterar i t.ex. fallet 
White mot Sverige (19.9.2006 § 21), måste journalister även vid rapporteringen av saker som väcker allmän oro grunda sin information på noggranna och exakta uppgifter och agera i god tro i enlighet med pressetiken. Särskilt i förhållande till rapportering som riktar sig mot namngivna personer måste särskilda skäl föreligga, för att mediet skall frigöras från sin plikt att påvisa riktigheten av faktiska påståenden som är kränkande för individen. Förhandenvarande särskilda skäl beror på påståendets karaktär och allvar samt i vilken mån mediet skäligen kan uppfatta sina källor som tillförlitliga.

EMD har betonat, att den i sin prövning inte bör göra sig själv till en fjärde rättsinstans i förhållande till de nationella myndigheterna. I stället bedömer den enbart huruvida den nationella domstolens dom är inom gränserna för den tillåtna prövningsmarginalen. ${ }^{19}$ En sameuropeisk uppfattning om inskränkningsgrundens objekt minskar statens prövningsmarginal och avsaknaden av en sådan ökar den. ${ }^{20}$ Den prövningsrätt som tillfaller staten är i regel bredare i ärenden som gäller t.ex. affärskonkurrens samt religion och moral, där någon sameuropeisk måttstock inte existerar. Möjligheterna att inskränka den politiska yttrandefriheten, som hör till yttrandefrihetens kärna, tolkas däremot snävt. ${ }^{21}$

I rättslitteraturen har man ansett att yttrandefriheten till och med getts ett alltför överdrivet skydd. ${ }^{22}$ Den företrädesställning som yttrandefriheten som utgångspunkt innehaft har dock vacklat i och med att EMD börjat ge en självständig betydelse åt skyddet för privatliv samt ära och rykte som ett skyddsobjekt enligt artikel 8 EMRK, och inte enbart som en godtagbar grund för inskränkning av yttrandefriheten enligt artikel 10(2) EMRK. Detta har föranlett även motsatta ställningstaganden, dvs. farhågor ifråga om yttrandefriheten. Den svåra avvägningen mellan skyddet för privatliv och yttrandefrihet framkommer även ur de skiljaktiga meningarna i domarna. ${ }^{23}$

\section{Skyddet för privatliv i Europeiska människorättsdomstolen}

\subsection{Begreppet privatliv och förpliktelsen att trygga}

Enligt artikel 8(1) EMRK har var och en rätt till skydd för sitt privat- och familjeliv, sitt hem och sin korrespondens. Enligt artikelns 2 stycke făr offentlig myndighet inte ingripa i denna rättighet annat än med stöd av lag och om det i ett demokratiskt samhälle är nödvändigt med hänsyn till den nationella säkerheten, den allmänna säkerheten eller landets ekonomiska välstånd, till förebyggande av oordning eller brott, till skydd för hälsa eller moral eller till skydd för andra personers fri- och rättigheter.

Vid sin tolkning av artikeln har EMD fastställt att den förutsätter att konventionsstaterna tryggar privatlivet mot kränkningar från enskilt håll. Det är alltså inte 
tillräckligt att staten själv avhåller sig från att kränka privatlivet, utan staten är även förpliktad att vid behov vidta aktiva åtgärder för att tillförsäkra realiseringen av skyddet för privatliv. Förpliktelsen att trygga förutsätter i flera fall skapandet och upprätthållandet av lagstiftning som skyddar privatlivet. ${ }^{24}$

EMD har gett en bred innebörd åt begreppet privatliv. I t.ex. målet Niemietz v. Tyskland (16.12.1992 § 29), som gällde en husrannsakan som gjorts i en advokatbyrå, ansåg EMD att det framför allt ifråga om självständiga yrkesutövare är svårt att skilja deras privatliv från deras yrkesutövning. Tillämpningsområdet för artikel 8 EMRK bör inte begränsas så snävt att det enbart skulle omfatta privatliv i hemmet. Skyddet för privatliv omfattar även rätten att skapa och utveckla relationer till andra människor, och arbets- eller yrkesverksamhet kan inte uteslutas ur denna omfattning, eftersom största delen av människoumgänget sker just inom ramarna för dylik verksamhet.

Skyddet för privatliv innefattar även egenskaper som hänför sig till den personliga identiteten, såsom en persons namn, fotografi samt fysiska och mentala integritet. Skyddet enligt artikel 8 EMRK är i första hand ämnat att säkerställa att envar kan utveckla sin personlighet och sina relationer till andra människor utan extern störning. Till privatlivets område hör en interaktionszon, som kan förekomma även i offentliga sammanhang. Publiceringen av t.ex. ett fotografi kan sålunda kränka privatlivet, även om personen på bilden vore allmänt känd. Begreppet privatliv omfattar även personlig information, som individen inte kan förmodas publicera utan samtycke. ${ }^{25}$

Enligt EMD:s tolkning omfattar artikel 8 EMRK även skyddet för ära och rykte, men inom ramarna för denna artikel är det dock inte möjligt att närmare behandla skyddet för ära och rykte. ${ }^{26}$ Däremot granskas i denna artikel i vilken mån individen skyddas mot spridande av i sig sanningsenliga uppgifter, antydningar eller bilder som berör dennes privatliv.

\subsection{Skyddet för privatliv som en grund för inskränkning av yttrandefriheten}

I EMD:s tidigare rättspraxis uppfattades skyddet för privatliv enbart som en godtagbar grund för inskränkning av yttrandefriheten i enlighet med artikel 10(2) EMRK. Delvis kan detta bero på att målen drivits som påstådda kränkningar av artikel 10 EMRK. Under den senaste tiden har EMD i sin avgörandepraxis emellertid ansett att privatlivets sfär omfattar den i artikel 8 EMRK tryggade rätten att skyddas mot offentliga avslöjanden av angelägenheter som gäller privatlivet eller oförtjänt förlust av rykte. ${ }^{27}$ Enligt EMD förtjänar yttrandefriheten och skyddet för privatliv »i princip« likvärdig respekt. På motsvarande sätt bör prövningsmarginalen »i teori« vara den samma, oberoende av om klaganden är en person som 
hänvisar till en kränkning av privatlivet eller en journalist eller ett mediebolag som klagar över en kränkning av yttrandefriheten. ${ }^{28}$ Även Europarådets parlamentariska generalförsamling framför i sin resolution 1165(1998) Right to Priva$c y$ punkt 11 att skyddet för privatliv och yttrandefriheten är likvärdiga.

Det tidigaste rättsfallet där skyddet för privatliv (i förhållande till yttrandefriheten) igenkändes torde vara avgörandet i målet Campmany y Diez Revenga mot Spanien (2.12.2000). I fallet hade en tidning rapporterat om vissa personers utomäktenskapliga förhållande jämte fotografier. Enligt EMD fokuserade tidningsartikeln fullständigt på privata angelägenheter. EMD godtog den intresseavvägning som utförts av de nationella domstolarna och ansåg att inblandningen med beaktande av statens prövningsmarginal var berättigad, varför skadeståndsdomen kunde anses nödvändig. I detta mål grundade EMD ännu inte sitt avgörande på artikel 8 EMRK, utan enbart på den godtagbara grunden för inskränkning av yttrandefriheten enligt artikel 10(2) EMRK. Även i fallet Bou Gibert mot Spanien (13.5.2003, beslut) godtog EMD de skadestånd som dömts ut till följd av avslöjandet av information rörande privatlivet, och ansåg klagomålet vara uppenbart ogrundat med stöd av artikel 10(2) EMRK.

I fallet »Wirtschafts-Trend« Zeitschriften-Verlagsgesellschaft mbH mot Österrike (14.11.2002, beslut) rapporterade en tidning att en namngiven polis misstänktes för lagstridiga förfaringssätt, då en person som skulle avvisas under oklara omständigheter hade dött under en flygresa. Händelsen hade väckt offentlig debatt kring de förfaringssätt som efterföljdes i samband med avvisningar, såsom bruket av handbojor och tejp. Tidningsbolaget hade dömts att betala ut ersättning åt den namngivne polisen, motsvarande en summa på 1800 euro, eftersom tillkännagivandet av dennes namn hade orsakat den misstänkte social marginalisering och »baktalande «. Enligt EMD hade de nationella myndigheterna motiverat fallet genom relevanta skäl med beaktande av oskyldighetspresumtionen i enlighet med artikel 6(2) EMRK och det faktum att tillkännagivandet av namnet inte hade medfört sådan tilläggsinformation av allmänt intresse som hade kunnat undantränga behovet av att hemlighålla namnet. Yttrandefriheten hade inte kränkts.

Fallets slutresultat kan med beaktande av det omfattande skydd som yttrandefriheten åtnjuter ses som överraskande, eftersom fråga var om ett dödsfall som inträffat vid tjänsteutövning, vilket hörde till området för en debatt av allmänt intresse och berättigat hade väckt stor uppmärksamhet i media. ${ }^{29}$ 


\subsection{Skyddet för privatliv som en rättighet tryggad av artikel 8 EMRK}

I fallet Société Prisma Presse mot Frankrike (1.7.2003, beslut) hänvisade EMD uttryckligen till artikel 8 EMRK. Fråga var om en artikel publicerad i en tidsskrift, där det rapporterades om sångaren Johnny Hallidays och dennes makas äktenskapskris och den abort som gjorts på Hallidays maka. EMD konstaterade att den av klaganden publicerade artikeln enbart hade strävat till att tillfredsställa en viss publiks nyfikenhet beträffande det äkta parets privatliv, och att den inte kunde anses främja diskussionen kring frågor av allmänt samhälleligt intresse, även om det äkta paret var allmänt känt. Grunderna för inskränkning av yttrandefriheten skulle tolkas mycket brett, eftersom tidningsartikeln och bilderna enbart rörde det personliga området. Det skadestånd på 200000 franc som dömdes ut till bägge makarna kränkte inte artikel 10 EMRK.

I fallet von Hannover mot Tyskland (24.6.2004 §§ 50-51), som gällde publiceringen av fotografier som tagits på prinsessan Caroline av Monaco, fastställde EMD i sitt avdelningsavgörande att skyddet för privatliv i enlighet med artikel 8 EMRK även ger skydd mot publicering av uppgifter eller bilder som berör personer. Enligt domen omfattar begreppet privatliv även aspekter som berör den personliga identiteten, såsom namn och bilder på en person. Privatlivet innefattar även personens fysiska och psykiska integritet. Enligt EMD är det primära syftet med artikel 8 EMRK att trygga individens personliga utveckling i förhållande till andra människor utan extern störning. Vid umgänget mellan människor finns därför - även i offentliga sammanhang - en interaktionszon som omfattas av privatlivet.

Trots att yttrandefriheten utsträcker sig även till publiceringen av fotografier, hade personernas rättigheter och skyddet för rykte en särskilt viktig betydelse vid publiceringen av fotografierna. Fotografierna som publicerats på klaganden framställde henne i alldagliga göromål, såsom cykelfärder eller butiksinköp, och således i fall av rent privat natur. Publiceringen av bilderna ingrep således i sfären för klagandens privatliv. Genom artiklarna och fotografierna hade man strävat till att tillfredsställa nyfikenhet $\mathrm{i}$ enbart en viss läsekrets, och de bidrog inte till någon debatt av samhälleligt intresse, trots att klaganden nog var känd för allmänheten. Under dessa omständigheter skulle yttrandefriheten tolkas snävare än vid behandlingen av t.ex. politiker i deras uppdrag.

Vid avvägningen mellan skyddet för privatliv och yttrandefriheten skulle det avgörande kriteriet vara publikationens bidrag till en debatt av allmänt intresse. Detta bidrag saknades eftersom prinsessan Caroline inte hade några offentliga uppdrag i Monaco, och eftersom fotografierna och artiklarna uteslutande berörde detaljer i hennes privatliv. Allmänheten hade inget godtagbart intresse av att veta 
var klaganden befann sig vid respektive tidpunkt och hur hon $\mathrm{i}$ allmänhet betedde sig i sitt privatliv. Klagandens privatliv hade kränkts i och med att den tyska lagstiftningen inte erbjöd ett tillräckligt skydd mot sådan verksamhet som förekommit i fallet.

EMD:s linjedragning var betydande och även något överraskande. Fråga var trots allt om en känd medlem av den kungliga familjen som framträtt mycket $\mathrm{i}$ offentligheten, och vars livsskeden pressen i olika länder kontinuerligt hade iakttagit. Då man drar slutsatser av fallet är det likväl skäl att komma ihåg att man i avgörandet även fäste uppmärksamhet vid de störande omständigheter som bilderna hade tagits under.

\section{Betydelsefulla kriterier att beakta vid avvägningen mellan yttrandefrihet och skydd för privatliv}

\subsection{Om EMD:s allmänna tolkningsprinciper}

EMD är inte bunden till sina tidigare avgöranden, men har dock ansett att rättssäkerheten, förutsebarheten och jämlikheten förutsätter att avvikelser inte görs från tidigare avgörandepraxis utan goda skäl. ${ }^{30}$ Omständigheterna i svarandestaten eller andra medlemsstater kan dock förändras med tiden, och därför kan även miniminivån på en mänsklig rättighet baserad på EMRK förändras. ${ }^{31} \mathrm{Ju}$ äldre avgörande av EMD det är fråga om, desto noggrannare måste övervägas huruvida omständigheter eller förhållningssätt som ändrats under tidens gång har försvagat dess betydelse $\mathrm{e}^{32}$ och huruvida avgörandet har någon tolkningseffekt under nutida omständigheter. ${ }^{33}$ Av betydelse är även huruvida avgörandet fattats i normal eller stor avdelning.

EMD:s tolkningssätt är dynamiskt och målinriktat. Ett effektivt tryggande av de rättigheter som tillförsäkras i konventionen förutsätter att EMRK uppfattas som ett levande instrument, som tolkas i enlighet med nutida omständigheter. ${ }^{34}$ Försummandet av ett dynamiskt och framåtskridande betraktelsesätt kunde äventyra förnyelse och utveckling och göra rättigheterna teoretiska och illusoriska istället för att de vore praktiska och effektiva. ${ }^{35}$

EMD har i flera mål granskat den nationella lagstiftningen och rättspraxisen i olika länder för att utreda den rådande skyddsnivån i Europarådets medlemsländer. Detta innebär ett slags bundenhet till europeisk rättskultur. ${ }^{36}$ EMD har även kunnat hämta tolkningsstöd av FN:s internationella konvention om medborgerliga och politiska rättigheter, om den varit mera detaljerad vad beträffar ifrågavarande rättighet. ${ }^{37} \mathrm{I}$ det följande granskas närmare de kriterier som är betydelsefulla vid avvägningen mellan yttrandefriheten och skyddet för privatliv. 


\subsection{Nyhetsrapporteringens betydelse som ett bidrag till en debatt av allmänt intresse}

Det första centrala bedömningskriteriet är huruvida den publicerade artikeln eller bilden bidrar till en debatt av allmänt intresse eller allmän betydelse (debate of general interest). Inte enbart debattämnen som gäller politiska frågor eller brottmål har ansetts bidra till debatter av allmänt intresse, utan även debatt som gäller idrott eller t.ex. uppträdande konstnärer kan komma på fråga. ${ }^{38}$ Till området för sådan debatt av allmänt intresse som åtnjuter ett omfattande yttrandefrihetsskydd har även debatt om metoder som använts vid sälfångst, polisens metoder vid undersökning av brott, invändningar om polisens våldsutövning, uppgifter om domstolsverkets verksamhet, skötseln av statsmedel, patientsäkerhet, patienters missnöje med plastikkirurgisk behandling, politisk tjänsteutnämning och ställningstaganden kring miljöskydd ansetts höra. ${ }^{39}$

Däremot har exempelvis offentliga personers människorelationer, Monacos prinsessa Carolines fritidssysselsättning, rykten kring det österrikiska presidentparets äktenskapsproblem och utomäktenskapliga förhållanden eller en sångares ekonomiska problem inte ansetts bidra till debatter av allmänt intresse. ${ }^{40}$ Vad beträffar presidentparet konstaterade EMD (Standard Verlags GmbH mot Österrike 4.6.2009 § 53) att även om rapporteringen om politikers eller andra offentliga personers privatliv i vissa situationer är tillåtet, kan även offentliga personer berättigat förmoda att deras privatliv skyddas och respekteras. Ett sådant skydd gäller t.ex. mot spridande av ogrundade rykten.

\subsection{Ställningen av den person som är objekt för rapportering}

Det andra betydande bedömningskriteriet är den persons roll eller uppgift som är objekt för nyhetsrapportering, samt hurdan information som rapporteras. Gemene man har störst skydd. Politiker och offentliga personer måste däremot underkasta sig större offentlighet. Politiker kan underkastas en normalt mera omfattande kritik, eftersom politisk debatt hör till yttrandefrihetens kärnområde och politiker frivilligt har åtagit sig att uppträda som galjonsfigurer för den politiska debatten, och därigenom oundvikligen och medvetet underkastat sina ord och handlingar granskning. Mellan gemene man och politiker befinner sig tjänstemännen, som inte underkastar alla sina ord och handlingar granskning i samma mån som politiker, men som ändå måste finna sig $\mathrm{i}$ att deras tjänsteåtgärder utsätts för kritisk granskning. ${ }^{41}$ Enligt EMD förutsätter en framgångsrik skötsel av tjänsteuppdrag dock att tjänstemän åtnjuter offentligt förtroende under omständigheter som inte är förknippade med osaklig störning. Sålunda kan det vara nödvändigt att skydda dem mot stötande och skymfande angrepp $i$ tjänsteutövningen. ${ }^{42}$ 
Skyddet för privatliv och rykte sträcker sig emellertid även till politiker, även då de inte agerar som privatpersoner. Härvid måste skyddet för rykte dock vägas i förhållande till intresset av en öppen politisk debatt. ${ }^{43}$ Även ifråga om politiker är det av relevans huruvida fråga är om en debatt som förs i ett demokratiskt samhälle, som hänför sig till exempelvis deras offentliga uppdrag. I särskilda fall kan allmänheten dock ha rätt att få kännedom även om offentliga personers, och särskilt politikers, privatliv. Detta är emellertid inte fallet då fotografier eller kommentarer enbart knyter an till personens privatliv och deras enda syfte är att tillfredsställa en viss publiks nyfikenhet. ${ }^{44}$

I fallet Saaristo mot Finland (12.10.2010 § 66) ansåg EMD att en person som anställts som central medarbetare i en valkampanj för en presidentkandidat och under denna tid var ledig från sin anställning som kommunikationschef $\mathrm{i}$ ett försäkringsbolag, och som var med i lokalpolitiken, inte var en tjänsteman eller politiker i ordets traditionella bemärkelse. Hon utgjorde emellertid inte en fullständigt privat person, eftersom hon representerade sin kandidats målsättningar i offentligheten och hörde till dennes närkrets. I denna ställning måste hon ha förstått att även hennes egen person skulle väcka offentligt intresse och att området för hennes skyddade privatliv sålunda vore mer begränsat än normalt. Enligt EMD:s åsikt (§§ 67-68) bidrog informationen om hennes utomäktenskapliga förhållande med den före detta maken till en televisionsreporter som ledde valdebatter till en debatt av allmänt intresse. Ytterligare var den påföljd, som bestod av 10 dagsböter och ersättning på 5000 euro (vilket tidningsbolaget till sitt belopp inte hade överklagat), som dömts ut för spridande av information som kränker privatlivet oproportionerligt hög. Yttrandefriheten hade sålunda inskränkts i strid med artikel 10 EMRK.

De finska rättsinstanserna hade betonat att valkampanjchefen inte själv kandiderade för någon tjänst eller befattning och att hennes personliga angelägenheter därför inte var av samhällelig betydelse. EMD ansåg dock att valkampanjchefen i detta uppdrag trätt fram på den offentliga arenan.

I fallet von Hannover mot Tyskland (24.6.2004) ansåg EMD att prinsessan Caroline av Monaco inte skulle jämställas med en politiker eller maktutövare enbart på basis av sin ställning, eftersom hon inte hade några offentliga uppdrag i staten eller dess myndigheter. EMD:s avgörande kan anses mycket formellt, eftersom prinsessan i en regentfamilj har en reell makt som exempelvis åsiktsbildare och förebild. Dessutom väcker kungliga personers levnadsvanor motiverat intresse, eftersom de använder offentliga medel.

I fallet Tammer mot Estland (6.2.2001) ansåg EMD att objektet för artikeln inte längre ett år efter att ha frånträtt sitt politiska uppdrag utgjorde en politisk el- 
ler offentlig person, även om hon fortfarande tillhörde ett politiskt parti. Ståndpunkten är förvånande, eftersom personens tidigare politiska verksamhet hade väckt stor uppmärksamhet på grund av bl.a. en skandal rörande hemlig inspelning och en politisk sexskandal. Dessutom var hon fru till en minister vid tillfället för nyhetsrapporteringen. EMD:s linje vad beträffar betydelsen av personens ställning kan alltså inte anses klar. Målsäganden i t.ex. det estniska fallet var en mycket mera politisk och offentligt synlig person än den finska målsäganden som var kommunikationsansvarig för en valkampanj.

Vissa grupper av människor kan däremot vara särskilt sårbara, vilket kan tala för en mera omfattande inskränkning av yttrandefriheten än normalt. I t.ex. fallet Handyside mot Förenade kungariket (7.12.1976) godtog EMD en mera omfattande inskränkning av yttrandefriheten än normalt, eftersom den moraliskt betänkliga boken var riktad till framför allt barn och unga i åldern 12-18 år.

\subsection{Inte ens en brottsling är skyddslös}

Situationer där i och för sig vanliga människor hamnat i centrum för uppmärksamhet såsom misstänkta för brott, åtalade eller dömda är svåra att bedöma. I fallet Egeland m.fl. mot Norge (16.4.2009) ansåg EMD inte att de böter på 10000 norska kronor (dryga 1300 euro) som dömts ut till respektive journalist för att ha brutit mot det fotograferingsförbud som föreskrivits i domstolslagen utgjorde en kränkning av artikel 10 EMRK. EMD (§ 62) ansåg att en situation där en person som dömts för ett trippelmord, och som samarbetat med pressen, inte kunde jämställas med situationer där personen frivilligt går ut i offentligheten i egenskap av politiker, offentlig person eller deltagare i en debatt av allmänt intresse. Man kan dock på goda grunder fråga sig huruvida inskränkningen av yttrandefriheten på de sätt som förutsätts i artikel 10(2) EMRK var nödvändig, då den dömdes identitet var känd genom att denne givit åtskilliga tidningsintervjuer, där denne även låtit sig fotograferas för tidningarna. Dessutom hade det publicerade fotografiet tagits på en offentlig plats strax efter offentliggörandet av domen för trippelmordet, alltså var det fråga om en aktuell nyhet gällande ett allmänt betydelsefullt ärende. Ytterligare kan man anse att en person inte vid begåendet av tre brott mot liv berättigat kan förmoda att hans privatliv kommer att skyddas till den del det rör sig om nyhetsrapportering kring mordrättegången. Denna ståndpunkt stöds av EMD:s dom i målet Sidabras m.fl. mot Litauen (27.7.2004 § 49), där domstolen ansåg att artikel 8 EMRK inte skyddar mot sådan förlust av rykte som är en förutsebar följd av personens eget agerande, såsom begående av brott.

Även EMD:s dom i fallet $A$ mot Norge (9.4.2009) gynnade skyddet för privatlivet. I fallet ansågs A:s skydd för ära och rykte, såsom en del av skyddet för pri- 
vatliv, ha kränkts då en tidning rapporterat att $\mathrm{A}$, som dömts för mord och redan avtjänat sitt straff, skulle höras i samband med undersökningen av ett annat mordfall, och att han sannolikt var den intressantaste av de tidigare dömda personer som polisen skulle förhöra. I rubriken på förstasidan nämndes att $\mathrm{A}$ bedyrar sin oskyldighet. I tidningen berättades att klaganden hade alibi. I berättelsen publicerades även en intervju med klaganden, där han bedyrade sin oskyldighet och berättade att han har vittnen gällande sitt alibi. Trots detta tillerkände EMD gottgörelse på 19000 euro för immateriell skada åt $\mathrm{A}$, som på basis av ett oklart fotografi och uppgifter gällande hans arbetsplats var identifierbar.

Fallen Egeland och A mot Norge är svåra att förstå då man jämför dem med fallen White mot Sverige (19.9.2006), Eerikäinen mot Finland (10.2.2009) och Iltalehti mot Finland (6.4.2010). I Egeland-fallet kan förklaringen utgöras av den breda nationella prövningsmarginalen, då även vissa andra länder hade fotograferingsförbud ifråga om rättegångar. Däremot är det svårt att relatera den konstaterade kränkningen av privatliv i fallet $A$ mot Norge till vissa andra fall rörande nyhetsrapporteringen kring rättegångar.

I t.ex. White-fallet rapporterade tidningarna bl.a. följande om klaganden: »Han pekas ut som PALMES MÖRDARE«. Ytterligare utgjorde klaganden enligt anonyma källor en person som man inte förråder obestraffat och som dödar utan en sekunds eftertanke. I historierna framfördes även påståenden om affärer med maffian, penningtvätt, täckoperationsverksamhet, vapen, droger, tjuvjakt samt smuggling som påstods ha skett bl.a. i Afrika. Den nationella domstolen hade ansett att skrivelserna objektiv sett var ärekränkande. Eftersom påståendena hade granskats hos de synnerligen få källor som var tillgängliga, och saken var samhälleligt betydelsefull, hade nyhetsrapporteringen varit berättigad. Enligt EMD hade klaganden beskrivits som en allvarlig brottsling, trots att han inte hade dömts för de påstådda brotten. Påståendena svärtade hans rykte och tog inte oskyldighetspresumtionen i beaktande. Historien hade dock kontrollerats hos de källor som hade varit tillgängliga. Under omständigheterna i fallet, och eftersom den nationella domstolen vid avgörande av saken på ett tillbörligt sätt hade gjort en avvägning mellan det allmänna intresse som hänförde sig till rapporteringen kring mordundersökningen och de intressen som hänförde sig till skyddet för klagandens privatliv och rykte, ansåg EMD inte att en kränkning av artikel 8 EMRK förelåg. Eventuellt kan även White-fallet förklaras med statens prövningsmarginal och likväl hade en »skälig« straff- eller ersättningsdom med beaktande av proportionalitetsprincipen kunnat godkännas av EMD.

I fallet Eerikäinen mot Finland (10.2.2009) ansågs yttrandefriheten ha kränkts, då en tidning hade dömts att betala skadestånd till ett belopp av ungefär 
3300 euro i och med att den vid rapporteringen om en bedrägerirättegång hade publicerat den åtalade kvinnans namn och bild. Enligt den finska domstolen var det fråga om nyhetsrapportering kring en viktig samhällelig angelägenhet, men i samband med den var det inte motiverat att avslöja den åtalades namn eller bild. Enligt EMD hade den småföretagare som åtalats för pensionsbedrägeri inte avsiktligt trätt ut på den »offentliga arenan« genom att för åtta år sedan ge en intervju i samband med ett annat ärende och genom att utöva en småskalig städbolagsverksamhet. Ställningen som åtalad i brottmålet fråntåg henne inte heller det skydd för privatliv som tryggas i artikel 8 EMRK. Fråga var emellertid om en angelägenhet av allmän betydelse, som allmänheten även med tanke på missbrukets omfattning hade rätt att fă kännedom om. Tidningsartikeln baserade sig på den offentliga åtalsskriften, och ur den framgick att det än så länge enbart var fråga om åtal. Ur högsta domstolens dom framgick inte huruvida särskild betydelse givits åt publiceringen av bilden. Dessutom hade bilden redan tidigare publicerats i ett annat sammanhang. Yttrandefriheten hade kränkts.

En kränkning av yttrandefriheten ansågs även föreligga i fallet Iltalehti och Karhuvaara mot Finland (6.4.2010). I fallet hade ett tidningsbolag dömts att betala ut 5000 euro i ersättning åt en väninna till den dåvarande riksförlikningsmannen, då tidningen genom att publicera en stor ansiktsbild på kvinnan hade rapporterat om att hon dömts till 20 dagsböter för misshandel. Rättegångsredogörelsen hänförde sig till en konflikt som uppstått hemma hos riksförlikningsmannen mellan riksförlikningsmannen och hans väninna samt riksförlikningsmannens fru och son. Till följd av händelserna fördes riksförlikningsmannen till häktet i hand- och fotbojor. Han hade senare avsatts från sitt uppdrag på grund av det skedda.

Enligt hovrätten hade man i samband med rapporteringen kring rättegången kunnat publicera namnet på väninnan och den bötesdom som dömts ut åt henne utan att kränka skyddet för privatlivet, trots att avslöjandet av identiteten på en person som ådömts ett lågt bötesstraff $\mathrm{i}$ regel inte var godtagbart. Publiceringen av en stor och uppseendeväckande ansiktsbild utgjorde en kränkning av privatlivet. EMD konstaterade att ställningen som åtalad i ett brottmål inte avlägsnade skyddet för privatliv. Genom att delta i orsakandet av offentlig störning utanför hemmet av sin gifta och offentligt kända manliga vän, kunde kvinnan dock anses ha trätt in i offentligheten. Avslöjandet av kvinnans identitet hänförde sig till ett ärende av allmänt intresse, dvs. riksförlikningsmannens handlande och hans möjligheter att fortsätta i den högt uppsatta tjänsten som riksförlikningsman.

Enligt min egen åsikt hade kvinnans namn eller fotografi, dvs. utseende, inget allmänt informationsvärde för bedömningen av riksförlikningsmannens möjlig- 
heter att fortsätta i sin tjänst. Ett dylikt argumentationssätt - som användes i fallet Gourguénidzé mot Georgien (17.10.2006) - fick emellertid inte fäste i Iltalehtieller Eerikäinen-fallet. ${ }^{45}$ En annan sak är huruvida inskränkningen av yttrandefriheten var nödvändig då kvinnans identitet redan framkommit via åtskilliga medier, eller i vilken mån uppgifter om begåendet av brott överlag hör till privatlivets sfär. Emellertid talar den ståndpunkt som EMD företrädde i Egeland-fallet mot betydelsen av dessa aspekter. ${ }^{46}$ EMD:s rättspraxis väcker likväl frågan om varför en person som dömts för ett trippelmord till det strängaste straff som tillåts i lag, och som redan tidigare hade givit intervjuer, fick skyddas mot publiceringen av ett fotografi (Egeland-fallet), medan en person som dömts till 20 dagsböter för misshandel (Iltalehti-fallet) eller åtalats för bedrägeribrott (och visserligen senare dömts till ett knappt två års villkorligt fängelsestraff, Eerikäinen-fallet) inte fick skyddas mot avslöjandet av deras bilder. Varför tillerkändes personer som åtalats eller dömts för lindrigare brott inte skydd för privatliv medan personer som dömts för brott mot liv ( $A$ - och Egeland-fallen) däremot skyddades? De norska fallen är svåra att förstå även vid en jämförelse av dem med det färska finska fallet Lahtonen mot Finland (17.1.2012), där den nationella domstolen hade skyddat en psykiskt sjuk gärningsmans privatliv genom att betrakta nämnandet av hans namn som en kränkning av privatlivet. Enligt EMD:s åsikt hörde nämnandet av gärningsmannens namn (vilket gjordes tiotals gånger i samma tidningsartikel) till ett objektivt skrivsätt och påföljderna (30 dagsböter och ersättning på 5000 euro) var dessutom oproportionerliga, varför yttrandefriheten hade kränkts.

\subsection{Rapporteringsobjektets tidigare aktivitet i media och informationens tidigare offentlighet}

EMD har även ansett det vara betydelsefullt huruvida rapporteringsobjektet själv sökt sig till offentligheten genom att avslöja detaljer om sitt privatliv. Framträdande $\mathrm{i}$ offentligheten minskar personens berättigade förmodan om nivån på sitt skydd för privatliv. ${ }^{47}$ Såsom framgår ur fallen Societe Prisma Presse mot Frankrike (1.7.2003, beslut), Egeland m.fl. mot Norge (16.4.2009 § 62) och Eerikäinen m.fl. mot Finland (10.2.2009 $\S 66$ ), avlägsnar tidigare samarbete med tidningar dock inte skyddet för privatliv ens vad beträffar brottsmisstänkta eller åtalade.

Av betydelse är även huruvida information i fråga redan tidigare publicerats $\mathrm{i}$ något medium. Detta grundar sig på att information som fătt omfattande spridning förlorar sin privata karaktär och det blir svårare att motivera nödvändigheten av att inskränka yttrandefriheten i enlighet med artikel 10(2) EMRK. Denna synpunkt framkom t.ex. i fallet Éditions Plon mot Frankrike (18.5.2004). I fallet godtog EMD en säkringsåtgärd om spridningsförbud av en bok som publicerats 
en och en halv vecka efter presidentens död, eftersom boken hade skrivits genom brott mot läkarens sekretessplikt, och kränkningen ökade de anhörigas lidande i och med att den gjorts under deras sorgetid. Säkringsåtgärdens förlängning i avgörandet $\mathrm{i}$ huvudsaken motsvarade dock inte ett trängande socialt behov, eftersom den offentliga debatten angående presidentens maktperioder efter sorgetiden måste tillmätas större vikt än krav till följd av läkarens brott mot sekretessplikten. Dessutom hade de uppgifter som publicerats i boken förlorat huvudparten av sin konfidentiella karaktär, emedan boken vid givandet av avgörandet $\mathrm{i}$ huvudsaken hade sålts i ungefär 40000 exemplar och den hade spritts på Internet och behandlats i media.

I fallet Reinboth mot Finland (25.1.2011) var det fråga om en redogörelse kring en rättegång om kränkning av privatlivet, där en repporter, med undantag av en bild, hade återgivit alla uppgifter vars spridning hade ansetts straffbart i den dom som givits föregående dag. Enligt EMD (§ 87) förelåg inget behov att hindra spridningen av uppgifterna, emedan de redan före rapporteringen hade varit tillgängliga för åtskilliga människor i två år. EMD stödde även sin ståndpunkt på fallet Fressoz och Roire mot Frankrike (21.1.1999). Det bör dock noteras att EMD för Finlands del i fallet Saaristo mot Finland (12.10.2010) hade ansett att de ifrågavarande uppgifterna om valkampanjchefens utomäktenskapliga förhållande hörde till området för en debatt av allmänt intresse, och att man inte hade fătt döma för spridande av information som kränker privatlivet till följd av publiceringen av dem. Sålunda förelåg givetvis inte heller skäl att hindra den senare spridningen av uppgifterna. I Fressoz-fallet var det däremot inte fråga om spridande av information som kränker privatlivet, utan om spridande av information angående en storföretagschefs även eljest offentliga skatteuppgifter i en situation där denne hade avslagit sina arbetsgivares krav på löneförhöjning, trots att han själv hade fătt en stor löneförhöjning.

Uppfattningen om att oberättigat publicerade uppgifter om privatlivet efter den första publiceringen fritt skulle få spridas passar dåligt ihop med artikel 8 EMRK som tryggar skyddet för privatliv - framför allt i en situation där nypubliceringen sker efter att en lång tid förflutit, och åter lyfter fram en gammal kränkning som den stora publiken redan hunnit glömma bort. Att tillåta spridandet av information som hör till sfären för privatlivet $\mathrm{i}$ andra medier än det som först publicerat den, skulle reducera skyddet för privatliv till nästan obefintligt. Förbudet att sprida information vidare kan som utgångspunkt åtminstone inte anses kränka privatlivet, då avvägningen mellan yttrandefrihet och skyddet för privatliv redan gjorts i samband med bedömningen av den första spridningens rättsstridighet. 
Det är dock ett obestridligt faktum att information, efter att ha fătt en bred spridning, förlorar sin privata karaktär, och i dylika situationer är det svårt att motivera nödvändigheten av att inskränka yttrandefriheten i enlighet med artikel 10(2) EMRK. Avgörandet torde vara nödvändigt att fattas från fall till fall, varvid man kan beakta t.ex. den publicerade informationens kvalitet och betydelse, informationsobjektet, publiceringens synlighet och hur lång tid som förflutit sedan den tidigare framträdande publiceringen av informationen.

\subsection{Införskaffningssättet av informationen och dess riktighet}

EMD har ansett att även införskaffningssättet av information är av betydelse i mål gällande skyddet för privatliv. I fallet von Hannover No. $l$ var en av de centrala faktorerna som inverkade på kränkningen av privatlivet att bilderna tagits i en atmosfär av kontinuerlig störning och rentav förföljelse. I fallet Eerikäinen mot Finland (10.2.2009 § 69; pensionsbedrägerirättegången) fäste EMD däremot vikt vid att de publicerade uppgifterna hade erhållits ur en offentlig åtalsskrift. I fallen Saaristo mot Finland (12.10.2010 § 65), Reinboth mot Finland (25.1.2011 $\S 85)$ och Axel Springer mot Tyskland (7.2.2012, stor avdelning, $\S \S 102-107)$ konstaterade EMD att det inte fanns några antydningar om att informationen hade erhållits genom svepskäl eller eljest genom olagliga metoder eller att informationen vore felaktig.

Vid bedömningen av skyddet för privatliv är informationens sanningshalt emellertid inte av samma betydelse som ifråga om skyddet för ära och rykte, eftersom skyddet för privatliv även, och framför allt, innefattar ett skydd mot publiceringen av sanningsenlig, men till privatlivets sfär hörande, information. Inte heller informationskällans offentlighet medför automatiskt en rätt att sprida informationen i massmedia, eftersom dokumentoffentligheten även omfattar ärenden som hör till privatlivets sfär. Nyhetsrapporteringen kring dem förutsätter inte nödvändigtvis en identifiering av informationsobjektet.

$\AA$ andra sidan innebär informationsinförskaffningssättets olaglighet inte alltid att det vore oberättigat att publicera informationen. I t.ex. fallet Novák mot Tjeckien (13.11.2003, beslut) ansåg EMD att publiceringen av samhälleligt betydande information som införskaffats genom olaglig avlysning inte kränkte privatlivet.

\subsection{Fotografiers särskilda skydd}

EMD har ansett att publiceringen av fotografier i allmänhet innebär en djupare inblandning i skyddet för privatliv än publiceringen av namn. ${ }^{48}$ I fallet von Hannover mot Tyskland No. 2 (7.2.2012 §§96 och 103) uttalade EMD att fotografier blottlägger en persons unika väsen och särskiljer henne från andra människor. 
Rätten till skyddet av egen bild utgör således en väsentlig del av den personliga utvecklingen. Till detta hör även rätten att kontrollera bruket av ens egen bild och förbjuda publiceringen av den. Trots att även publiceringen av bilder omfattas av yttrandefriheten, erhåller skyddet för andras rättigheter och rykte en särskild betydelse inom detta område, eftersom fotografier kan innehålla mycket personlig och till och med intim information om individen eller dennes familj. Bilder som publicerats i sensationstidningar har ofta tagits i en atmosfär av konstant störning, vilket redan i sig skapar en känsla av förföljelse eller inkräktande i privatlivets sfär.

I fallet Gourguénidzé mot Georgien (17.10.2006) hade en person sålt en känd författares manuskript. EMD ansåg att personens privatliv hade kränkts, då hans bild hade publicerats i en tidningsartikel där han beskylldes för att ha stulit manuskriptet. EMD konstaterade att publiceringen av klagandens fotografi inte hade gett någon tilläggsinformation om behandlingen av ett i sig betydelsefullt ärende, utan dess syfte hade enbart varit att karaktärisera klagandens person.

I fallet Reklos m.fl. mot Grekland (15.1.2009) ansåg EMD att fotograferandet av klagandens nyfödda barn på sjukhusets sterila avdelning inte hänförde sig till händelser som kunde inspelas eller refereras offentligt. Bilderna hade emellertid inte spridits till allmänheten, utan man hade enbart försökt sälja dem till föräldrarna. Enligt EMD skall en person ha rätt att bestämma om sin bild och spridandet av den och på samma gång även om tagandet, förvaringen och kopieringen av den. Sålunda måste även under vederbörande förhållanden förutsättas att personens samtycke införskaffas redan till tagandet av bilden och inte enbart till ett eventuellt offentligt spridande av den. Klagandena hade inte gett sitt samtycke till fotograferingen och objektet för bilderna hade inte varit en aktuell eller eljest offentlig person, vilket i vissa situationer hade kunnat berättiga fotograferingen utan samtycke med tanke på det allmänna intresset. Ytterligare hade fotografen trots klagandenas invändningar själv behållit negativen, varvid det var möjligt att senare använda dem utan barnets eller dennes föräldrars samtycke. Under dessa omständigheter, och då de nationella domstolarna inte hade godtagit klagandenas ersättningsyrkande, ansåg EMD att artikel 8 EMRK hade kränkts.

Enligt min åsikt utgör fallet än en gång ett bevis på hur svårt det är att förutse EMD:s avgörandepraxis. Det står klart att den nyfödda inte kunde lida men av fotograferingen. Bilderna var inte känsliga, varför det även förelåg synnerligen liten fara för att de senare skulle skapa eventuell skada. Ytterligare hade man senare eventuellt kunnat ingripa i publiceringen eller annat missbruk av dem genom enskilda rättsmedel. Jag anser det även möjligt att avgörandets betydelse i första hand begränsar sig till situationer, där den fotograferade befinner sig i en under- 
ordnad ställning (såsom patient eller barn) och där bilderna tagits på en skyddad plats (t.ex. ett sjukhus), där den som uppehåller sig har en berättigad förmodan om integritet.

Även EMD:s dom i fallet MGN Limited mot Förenade kungariket, (18.1.2011; röst. 6-1), som gällde publiceringen av ett fotografi på supermodellen Naomi Campbell, kan anses överraskande. Tidningen hade berättat att Naomi Campbell, som var en supermodell av världsklass, deltog i möten för anonyma narkomaner för att bli kvitt sitt alkohol- och drogmissbruk, och att hon hade förts till sjukhus för magtömning. Enligt Campbell hade hon inte några drogproblem och magtömningen hade enbart berott på en allergisk reaktion. I samband med artikeln publicerades ett fotografi där Campbell höll på att anlända till ett gruppmöte för anonyma narkomaner.

Tidningsbolaget anförde klagomål till EMD angående kränkning av yttrandefriheten, emedan bolaget hade dömts att betala skadestånd och rättegångskostnader till Campbell på grund av publiceringen av bilden. EMD konstaterade att publiceringen av fotografier i skvallertidningar i allmänhet skedde $i$ en atmosfär av konstant trakasseri, vilket kunde väcka känslor om grov integritetskränkning eller till och med förföljelse. Med beaktande av prövningsmarginalen ansåg EMD att den inte utan vägande skäl kunde komma till ett annat resultat än majoriteten i House of Lords, som hade ansett att publiceringen av bilderna hade äventyrat Campbells avvänjningsbehandling och orsakat henne betydande mentalt lidande. Publiceringen av tilläggsuppgifterna var inte nödvändigt för att garantera historiens tillförlitlighet och allmänheten hade inget trängande behov att erhålla information om dessa angelägenheter. Det offentliga intresset hade tillgodosetts redan genom att de grundläggande uppgifterna om drogberoendet och behandlingen publicerats. Under dessa omständigheter ansåg EMD att artikel 10 EMRK inte hade kränkts genom utdömandet av skadestånd på grund av publiceringen av bilderna. De överenskomna rättegångskostnaderna (success fee) på 500000 pund som baserade sig på resultatpremier (ursprunglig summa 850000 pund) kränkte däremot yttrandefriheten på grund av sin oproportionerliga storlek.

Själv vore jag benägen att anta minoritetens ståndpunkt i målet. Den medlem som blev i minoritet uttalade, att Campbell var en känd supermodell och synnerligen känd offentlig person, som lögnaktigt hade nekat till att ha använt droger och strävat till att skaffa ekonomisk vinning genom upprätthållandet av en felaktig image. Majoriteten i EMD hade fäst stor vikt vid den prövning som utförts av den nationella domstolen. Enligt minoriteten var detta betraktelsesätt dock såsom framkom i bl.a. de finska fallen Flinkkilä m.fl. mot Finland (6.4.2010) och Mariapori mot Finland (6.7.2010) - i strid med den stränga granskning som 
EMD vanligtvis gjort i yttrandefrihetsmål genom att väga skyddet för privatliv mot yttrandefriheten. Vanligtvis hade EMD utfört en självständig bedömning, oavhängig av den nationella domstolens värdering.

\subsection{Påföljdernas proportionalitet}

Bedömningen av påföljdernas proportionalitet utgör en del av bedömningen av nödvändigheten av inskränkningar av yttrandefriheten. Med påföljder avses såväl straff som skadeståndsansvar. Även en oproportionerligt stor ersättning av rättegångskostnader kan kränka yttrandefriheten.

Enligt EMD är vidtagandet av straffrättsliga medel mot kränkningar av ära eller privatliv inte som sådant oproportionerligt i förhållande till syftet. Hot om fängelse för »pressbrott« (press offence) i anknytning till offentliga debatter passar emellertid enbart undantagsvis ihop med pressfriheten såsom den garanteras av artikel 10 EMRK. Detta gäller bl.a. då andra grundläggande rättigheter har kränkts genom t.ex. hets mot folkgrupp eller genom anstiftan till brott. ${ }^{49}$

EMD:s avgörandepraxis är svår att förutse även ifråga om bedömningen av påföljdernas proportionalitet. Vid bedömningen av straff- och skadeståndsrättsliga påföljders stränghet har inte enbart straffens eller skadeståndens kvantitet som sådan varit avgörande, utan betydelse har även tillmätts det framförda påståendets allvar samt t.ex. hur likgiltigt journalistens skyldigheter har försummats. I fall av uppenbart missbruk av yttrandefriheten har EMD godtagit tämligen kännbara påföljder. ${ }^{50}$

I t.ex. fallet Ruokanen mot Finland (6.4.2010, beslut) ansåg EMD att de ersättningar på 59000 euro för lidande och de rättegångskostnader på 30000 euro som dömts ut till målsägandena, samt de straff på 60 dagsböter (3 540 euro till chefredaktören och 1920 euro till redaktören) som i sig konstaterats vara stränga, med beaktande av de allvarliga påståendena om våldtäkt och statens prövningsmarginal var godtagbara, varför yttrandefriheten inte hade kränkts. Fråga var visserligen om ärekränkning på grund av spridande av osann information, inte om kränkande spridning av information om privatlivet. I fallet Yleisradio m.fl. mot Finland (8.12.2011, beslut) som gällde ett televisionsprogram som kritiserat utredningen i ett sexualbrottsmål, vilket i sig gällde en debatt av allmänt intresse, godtog EMD de straff på 50 dagsböter (3900 euro till chefredaktören och 1850 euro till redaktören) som svarandena dömts till och de skadestånd på sammanlagt 15000 euro samt de rättegångskostnader på nästan 18000 euro som dömts ut till offren för spridande av information som kränker privatlivet. I fallet Saaristo m.fl. mot Finland (12.10.2010) ansåg EMD däremot att straffen på 10 dagsböter (270 euro till redaktören och 650 euro till chefredaktören) som journalister dömts till 
för kränkande av en valkampanjchefs privatliv samt ersättningen på 5000 euro för lidande, som svarandena till sitt belopp inte hade överklagat, och rättegångskostnaderna på 6500 euro utgjorde oproportionerligt stora påföljder i jämförelse med det största skadestånd på 17000 euro som dömts ut till ett offer som allvarligt invalidiserats genom misshandel.

Att EMD:s avgörandepraxis är svår att förutse påvisas även av att EMD i fallet $A$ mot Norge (9.4.2009) själv tillerkände 19000 euro gottgörelse för immateriell skada orsakad av tidningsrapportering åt en person som gjort sig skyldig till brott mot liv men avtjänat sitt straff, trots att domstolen i fall som gällt Finland har ansett medieersättningar på 5000 euro vara oproportionerligt stora. En gottgörelse på 19000 euro som tillerkänns en mördare är även stor i förhållande till de ersättningssummor på ca 5000 euro som EMD dömt ut till journalister i fall som gällt yttrandefrihetskränkningar.

Ersättningsnivåns godtagbarhet påverkas i EMD även av huruvida yttrandefriheten brukats i en politisk debatt eller i en offentlig debatt av s.k. allmänt intresse eller om den enbart brukats i en debatt av rent underhållningsmässig karaktär eller som syftar till att tillfredsställa allmän nyfikenhet. Vad beträffar offentliga debatter av politiskt eller allmänt intresse är statens prövningsmarginal markerat snäv och sålunda kan även ersättningsnivån lättare anses alltför hög. I t.ex. fallet Lopes Gomes da Silva mot Portugal (28.9.2000 § 36) lade EMD inte någon större betydelse vid ringheten av det straff som klaganden dömts till, utan snarare vid själva dömandet. ${ }^{51}$ I fallet Brasilier mot Frankrike (11.4.2006), som gällde en offentlig debatt där parlamentsvalets laglighet ifrågasatts, ansåg EMD däremot att ersättningsskyldigheten på 1 franc nog var skälig som sådan men ändå inte i sig berättigade ingripandet i klagandens yttrandefrihet.

Bedömningen påverkas även av den allmänna skadeståndsnivån i landet $\mathrm{i}$ fråga. I t.ex. de finska fallen har medieersättningarna ofta jämförts med den relativt låga nivån på ersättningar för personskador, varvid medieersättningar i jämförelse kan verka oproportionerligt stora. De skadestånd som media dömts att betala måste likväl stå i ett proportionerligt förhållande till de skadestånd som dömts ut för andra typer av immateriell skada i vederbörande land.

\section{Slutsatser}

I och med att skyddet för privatlivet stärkts har EMD:s avgörandepraxis ifråga om yttrandefrihetsmål blivit allt mer oförutsebar. Framför allt information i form av bilder har i vissa fall åtnjutit ett förvånansvärt stort skydd. Enligt Flauss finns det förvridningar och inkonsekvenser i rättspraxisen gällande yttrandefrihetsmål, vilka försvagar begripligheten och auktoriteten av EMD:s rättspraxis. Enligt ho- 
nom äventyras rättssäkerheten då de olika avdelningarnas avgörandemetoder avviker från varandra. ${ }^{52}$

De principer som EMD traditionellt tillämpat, såsom det höga skyddet av yttrandefriheten och pressens viktiga betydelse som offentlig vakthund, är fortfarande i kraft, men deras betydelse har i vissa fall verkat lägre än tidigare. Ytterligare har tillämpningen av allmänna principer på enskilda mål $\mathrm{i}$ vissa fall verkat inkonsekvent. Även tillämpningen av prövningsmarginalsdoktrinen har varit vacklande.

Rättspraxisens oenhetlighet innebär för de nationella domstolarnas del tyvärr att strävan till slutresultat som stämmer överens med EMRK blir allt svårare att realisera samtidigt som man genuint och allvarligt börjat ta de mänskliga rättigheter i beaktande. Om EMD:s rättspraxis verkar alltför motstridig eller luddig kan den i värsta fall bryta ned det värde som sätts på avgöranden och med tiden leda till att klandervärdet av brottmålsdomar minskar. Det återstår att se huruvida stora avdelningens yttrandefrihetsgynnsamma domar av 7.2.2012 (von Hannover No. 2 och Axel Springer $A G$ ) har en förenhetligande verkan på kommande avdelningsavgöranden.

\section{Noter}

1. Jag tackar professor Dan Frände, docent Jussi Matikkala och JD, förvaltningsråd (f.d. domare vid EMD) Matti Pellonpää för värdefulla kommentarer som förbättrat artikeln. Skribenten bär givetvis själv allt ansvar för eventuella fel och brister i texten.

2. Päivi Tiilikka är docent i kommunikationsrätt (2011). Hon har arbetat som forskare vid Helsingfors universitet sedan november 2003. Hennes huvudsakliga forskningsområden är medie- och kommunikationsrätt, konstitutionell rätt, mänskliga rättigheter, skadeståndsrätt och tryck- och yttrandefrihetsbrott.

3. Nicol QC, Andrew - Millar, Gavin QC - Sharland, Andrew: Media Law \& Human Rights. 2nd ed. Oxford 2009 s. 37 konstaterar att statens aktiva förpliktelse att skydda mot medieoffentlighetens intrång kan betraktas som den mest betydande förändringen i medierätten under de senaste tio åren.

4. T.ex. Informationsverein Lentia m.fl. mot Österrike (24.11.1993 §§ 38-39) och Özgür Gündem mot Turkiet (16.3.2000 § 71).

5. Nicol-Millar - Sharland 2009 s. 26. Om kravet på föreskrivning i lag Pellonpää, Matti: Europeiska människorättskonventionen. Helsinki 2007 s. 252-256 och Viljanen, Jukka: The European Court of Human Rights as a Developer of the General Doctrines of Human Rights Law. Tampere 2003 s. 185-208. I rättspraxis har saken granskats i t.ex. målen Markt Intern Verlag GmbH och Klaus Beermann mot Tyskland (20.11.1989 § 30), Wingrove mot Förenade kungariket (25.11.1996 §§ 40 och 42), Worm mot Österrike (29.8.1997 § 38), Ahmed m.fl. mot Förenade kungariket (2.9.1998 §§ 46-48), Societe Prisma Presse mot Frankrike (1.7.2003 beslut), Leyla Sahin mot Turkiet (10.11.2005 §§ 88-98), Sciacca mot Italien (11.1.2005 § 30), Eerikäinen m.fl. (10.2.2009 § 58), Iltalehti 
m.fl. (6.4.2010 §§ 42-44), Reinboth m.fl. (25.1.2011 §§ 70-73) och Lahtonen mot Finland (17.1.2012 §§ 57-60).

6. EMD använder kontinuerligt samma kriterier, se t.ex. angående affärskonkurrens och yttrandefrihet målet Markt Intern Verlag GmbH och Klaus Beermann mot Tyskland (20.11.1989 § 30), angående ärekränkning målen Perna mot Italien (6.5.2003 §§ 39 och 48) och Radio France mot Frankrike (30.3.2004 §§ 39-41) samt angående skyddet för privatliv målet Karhuvaara och Iltalehti mot Finland (16.11.2004 §§38-39 och 54).

7. Statistik återfinns på adressen http://www.echr.coe.int/NR/rdonlyres/2B783BFF-39C9455C-B7C7-F821056BF32A/0/TABLEAU_VIOLATIONS_EN_2011.pdf. Övriga uppgifter har insamlats på domstolens sökdatabas HUDOC. Någon kränkning konstaterades inte $\mathrm{i}$ fallet White mot Sverige (19.9.2006) eller Yleisradio mot Finland (12.6.2009).

8. T.ex. HD 2001:96, 2002:55, 2005:82, 2005:136 (förstärkt sammansättning), 2006:20, 2010:39 och 2011:72. Om spridande av information som kränker privatlivet, se Tiilikka, Päivi: Sananvapaus ja yksilön suoja. Lehtiartikkelin aiheuttaman kärsimyksen korvaaminen. Vantaa 2007 s. 435-531 och Tiilikka, Päivi: Sananvapaus, yksilönsuoja ja lähdesuoja Ruotsissa, Norjassa ja Alankomaissa sekä Euroopan ihmisoikeustuomioistuimen ratkaisukäytännössä. Oikeusministeriö, Selvityksiä ja ohjeita 54/2010. Justitieministeriet tillsatte 30.9.2011 en arbetsgrupp med uppgift att granska strafflagens bestämmelser om yttrandefrihetsbrott samt behovet av att revidera dessa bestämmelser utgående från EMD:s avgörandepraxis. Arbetsgruppen överlämnade sitt betänkande med ändringsförslag 16.4.2012. Skribenten av denna artikel var medlem i arbetsgruppen.

9. I Norge har en ny bestämmelse om kränkning av privatliv stadfästs, $267 \S$ i strafflagen (LOV 2005-05-20 nr 28: Lov om straff), som ännu inte trätt i kraft.

10. Eggen, Kyrre: Ytringsfrihet. Vernet om ytringsfriheten i norsk rett. Oslo 2002 s. 722-723 och 726. Om skyddet för privatliv ibid. 722-739 och Borvik, Bjønar: Personvern og ytringsfridom. Avveginga mellom kolliderande menneskerettar. Universitetsforlaget 2011.

11. Eggen 2002 s. 726.

12. Greve, Vagn m.fl: Kommenteret straffelov, Speciel del. København 2008 s. 430-435. Se även Schaumburg-Müller, Sten: PresseRet. København 2003 s. 160.

13. Se om detta t.ex. Brott mot personuppgiftslagen - Rekommendationer vid handläggning av misstankar om brott mot PUL, 2012 s. 7-8.

14. Se Axberger, Gunnar: Ära och integritet. Juridisk Tidskrift 1994-1995 s. 717-718 och betänkandet Fotografering och integritet, SOU 1974:85, delbetänkandet Fotografering och integritet, SOU 1974:84, delbetänkandet Reklam och integritet, SOU 1976:48 ( $\Rightarrow$ lag om namn och bild i reklam; 1978:800), betänkandet Privatlivets fred, SOU 1980:8, betänkandet Värna yttrandefriheten, SOU 1983:70, delbetänkandet Integritetsskyddet i informationssamhället 3. Grundlagsfrågor, Ds Ju 1987:8, ministeriets promemoria Skyddet för enskilda personers privatliv, Ju 1992:C, Skyddet för enskilda personers privatliv - En studie, Ds 1994:51, betänkandena Ersättning för kränkning genom brott, SOU 1992:84, Skyddet för den personliga integriteten - kartläggning och analys, SOU 2007:22: Del 1, 535 s. och Del 2, 603 s. samt Skyddet för den personliga integriteten, Bedömningar och förslag; SOU 2008:3, 357 s. Integritetsskyddet och integritetsskyddskommitténs betänkande har bedömts i SvJT:s temanummer 4/20009, som innehåller flera artiklar kring temat. I lagrådsremissen (1.3.2012) föreslås att ett nytt brott benämnt kränkande fotografering införs i brottsbalken. 
15. SOU 2007:22, Del 1 s. 442. Se även SOU 2009:14 s. 107-114.

16. Denna tolkningslinje har en lång tradition, se t.ex. Handyside mot Förenade kungariket (7.12.1976 § 49), Éditions Plon mot Frankrike (18.5.2004 § 42), Lindon, OtchakovskyLaurens och July mot Frankrike (22.10.2007, stor avdelning § 45), Jerusalem mot Österrike (27.2.2001 § 32), Iltalehti m.fl. mot Finland (6.4.2010 § 46), Axel Springer AG mot Tyskland (7.2.2012, stor avdelning § 78) och von Hannover mot Tyskland No. 2 (7.2.2012, stor avdelning $\S 101)$.

17. T.ex. Bladet Tromsø m.fl. mot Norge (20.5.1999, stor avdelning $\S \S 59$ och 62), Perna mot Italien (6.5.2003 § 39), Pedersen och Baadsgaard mot Danmark (17.12.2004, stor avdelning § 71), Axel Springer AG mot Tyskland (7.2.2012, stor avdelning § 79) och von Hannover mot Tyskland No. 2 (7.2.2012 § 102).

18. T.ex. Castells mot Spanien (23.4.1992 § 42), Dalban mot Rumänien (28.9.1999, stor avdelning § 49), Jerusalem mot Österrike (27.2.2001 § 32), Vides Aizsardzibas Klubs mot Lettland (27.5.2004 § 40) och Ukrainian Media Group mot Ukraina (29.3.2005 § 40).

19. Jerusalem mot Österrike (27.2.2001 § 33), Ukrainian Media Group mot Ukraina (29.3.2005 § 43), Egeland och Hanseid mot Norge (16.4.2009 §§ 50-55) och Saaristo mot Finland (12.10.2010 $\S \S 56-57)$. Angående prövningsmarginalen, se t.ex. de skiljaktiga medlemmarnas (5 st.) utlåtande i fallet Axel Springer AG mot Tyskland (7.2.2012, stor avdelning).

20. Yourow, Howard Charles: The Margin of Appreciation Doctrine in the Dynamics of European Human Rights Jurisprudence. Netherlands 1996 s. 194 och t.ex. Sunday Times mot Förenade kungariket (stor avdelning $\S \S 58-69$ ).

21. T.ex. den tidigare EMD-domaren, Raimo Pekkanens skrifter Tuomiovalta ja tiedotusvälineet. Lakimies 1997a s. 17-24, s. 23-24 och Sananvapaudesta uskontoa ja rasismia koskevissa asioissa. Lakimies 1997b s. 646-655, s. 648-649 och 652. Viljanen, Jukka: Euroopan ihmisoikeussopimuksen rajoituslausekkeiden tulkinnan yhteys perusoikeusuudistukseen kohti yleistä perus- ja ihmisoikeuksien rajoituskriteeristöä. Oikeus 1995 s. 372-382, s. 373374. Angående den breda prövningsmarginal som hänför sig till moral även Pellonpää, Matti: Euroopan neuvoston ihmisoikeussopimus Suomen näkökulmasta. Oikeusministeriön lainvalmisteluosaston julkaisu 21/1988. Helsinki 1989 s. 202. Om rättspraxis se t.ex. Markt intern Verlag GmbH och Klaus Beerman mot Tyskland (20.11.1989, röst. 9-9 § 37), Handyside mot Förenade kungariket (7.12.1976 § 49), Müller m.fl. mot Schweiz (24.3.1988 §§ 35-36) och Otto-Preminger-Institut mot Österrike (20.9.1994 § 50).

22. Flauss, Jean-François: The European Court of Human Rights and the Freedom of Expression. Indiana Law Journal Vol. 842009 s. 809-849, s. 846 konstaterar att skyddet för rykte i regel getts en mindre betydelse än yttrandefriheten, varför individerna blivit »gisslan« för sådana »allmänt intresseväckande diskussionsteman« som åtnjuter ett brett yttrandefrihetsskydd. Enligt Flauss åsikt har det överdrivna skyddandet (»overprotection«) av yttrandefriheten dock minskat i senaste tids rättspraxis.

23. Voorhoof, Dirk - Cannie, Hannes: Freedom of Expression and Information in a Democratic Society, The Added but Fragile Value of the European Convention on Human Rights. The International Communication Gazette 2010 s. 407-422, s. 420-422. Se t.ex. stora avdelningens skiljaktiga meningar i målen Lindon m.fl. mot Frankrike (22.10.2007) och Stoll mot Schweiz (10.12.2007). Se även Flux No. 6 mot Moldavien (29.7.2008), där en av do- 
marna i sin skiljaktiga mening uttalade: »this judgment of the Court has thrown the protection of freedom of expression as far back as it possibly could«, making it »a sad day for freedom of expression«.

24. Om den positiva förpliktelsen att trygga t.ex. Schüssel mot Österrike (21.2.2002 § 2), Novák mot Tjeckien (13.11.2003, beslut), Pfeifer mot Österrike (15.11.2007 § 37), K.U. mot Finland (2.12.2008 §§ 42-43) och von Hannover mot Tyskland No. 2 (7.2.2012, stor avdelning $\S 98)$.

25. von Hannover mot Tyskland No. 1 (24.06.2004 §§ 50-53), Sciacca mot Italien (11.1.2005 29) och von Hannover mot Tyskland No. 2 (7.2.2012 § 95). Se även Petrina mot Rumänien (14.10.2008 § 27). Dylik information kan avse t.ex. personens människorelationer, hälsotillstånd eller fritidssysselsättningar.

26. T.ex. Radio France m.fl. mot Frankrike (30.3.2004), Cumpănă och Mazăre mot Rumänien (17.12.2004, stor avdelning), Sanchez Cardenas mot Norge (4.10.2007 § 38), Pfeifer mot Österrike (15.11.2007 § 35) och A mot Norge (9.4.2009 § 64).

27. I tidigare rättslitteratur behandlades $\mathrm{i}$ allmänhet överlag inte skyddet för privatliv som ett skydd mot avslöjande av uppgifter eller framförande av påståenden gällande personer. Ett undantag till detta utgörs t.ex. av Eggen (2002 s. 721-722) som ansåg att de stater som bundit sig till människorättskonventionen ska upprätthålla normer som ger skydd mot publiceringen av uppgifter som berör privatlivet. Se även Rytter, Jens Elo: Den Europæiske Menneskerettighedskonvention - og dansk ret. København 2003 s. 136-137 och Schaumburg-Müller 2003 s. 136-195.

28. von Hannover mot Tyskland No. 2 (7.2.2012 § 106) och Axel Springer AG mot Tyskland (7.2.2012 §§ 87). På liknande sätt Hachette Filipacchi Associés (ICI PARIS) mot Frankrike (23.7.2009 § 41) och Mosley mot Förenade kungariket (10.5.2011 § 111).

29. Man kan visserligen hävda att polisens identitet saknade betydelse med tanke på sakens nyhetsvärde, men ändå har EMD godtagit publiceringen av namnet på misstänkta (Eerikäinen ym., 10.2.2009) och dömda (Lappalainen, 12.1.2009, beslut) personer samt personer som inte dömts på grund av otillräknelighet (Lahtonen, 17.1.2012) i mål som gällt Finland.

30. T.ex. Chapman mot Förenade kungariket (18.1.2001 § 70).

31. Pekkanen, Raimo: Sananvapaudesta Euroopan ihmisoikeussopimuksen mukaan, i verket Juhlajulkaisu Antti Suviranta 1923-30/11-1993. Helsinki 1993 s. 132, Schaumburg-Müller 2003 s. 84 och Thorgeirsdóttir, Herdis: Journalism Worthy of the name. Freedom within the Press and the Affirmative Side of Article 10 of the European Convention on Human Rights. Leiden/Boston 2005 s. 54. Se även Pellonpää, Matti: Euroopan ihmisoikeustuomioistuin ja uudet sopimusvaltiot. Lakimies 1999 s. 1049-1060, s. 1049.

32. Nicol-Millar-Sharland 2009 s. 12.

33. Bull, Thomas: På yttrandefrihetens yttersta gren. JT 2006 s. 514-535, s. 519.

34. T.ex. Tyrer mot Förenade kungariket (25.4.1978 § 31) och Matthews mot Förenade kungariket (18.2.1999 § 39).

35. T.ex. Christine Goodwin mot Förenade kungariket (11.7.2002 § 74, stor avdelning, röst.). Se även Cossey mot Förenade kungariket (27.9.1990, röst.) och Stafford mot Förenade kungariket (28.5.2002, röst. §§ 68-69) och Nicol - Millar - Sharland 2009 s. 13.

36. Pellonpää 2007 s. 246 och 1999 s. 1057-1059. T.ex. Vo mot Frankrike (8.7.2004, stor avdelning, röst.), Evans mot Förenade kungariket (10.4.2007, stor avdelning, röst.) och Ege- 
land mot Norge (16.4.2009). Granskningen kan rikta sig även till andra länder, se Christine Goodwin mot Förenade kungariket (11.7.2002 §§ 84-85) och Nikula mot Finland (21.3.2002 §22).

37. Pellonpää 2007 s. 246 . Se koncist om rättskomparativa synpunkter ibid. 243-250.

38. Tammer mot Estland (4.4.2001 § 65), von Hannover mot Tyskland No. 1 (24.6.2004 § 60), Standard Verlags GmbH mot Österrike No. 2 (4.6.2009 § 46), White mot Sverige (19.9.2006 § 29), Egeland m.fl. mot Norge (16.4.2009 § 58), Leempoel \& S.A. ED. Ciné Revue mot Belgien (9.11.2006 § 72), Nikowitz m.fl. mot Österrike (22.2.2007 § 25), Colaço Mestre m.fl. mot Portugal (26.4.2007 § 28), Sapan mot Turkiet (8.6.2010 § 34), Axel Springer AG mot Tyskland (7.2.2012 § 90) och von Hannover mot Tyskland No. 2 (7.2.2012§109).

39. Bladet Tromsø och Steensaas mot Norge (20.5.1999 § 66), Pedersen och Baadsgaard mot Danmark (19.6.2003, stor avdelning, röst. § 78), Thorgeir Thorgeirson mot Island (25.6.1992 § 67), Rizos och Daskas mot Grekland (27.5.2004 § 42), Dalban mot Rumänien (28.9.1999 § 49), Selistö mot Finland (16.11.2004 § 48), Bergens Tidende mot Norge (2.5.2000 § 49), Rodrigues mot Portugal (29.11.2005 § 29), Mamere mot Frankrike (7.11.2006 §§ 23 och 25) och Iltalehti mot Finland (6.4.2010 § 53). Se även Axel Springer $A G$ mot Tyskland (7.2.2012, stor avdelning), där en skådespelare som var känd för sin roll som poliskommissarie hade blivit fast för kokaininnehav, vilket bidrog till en debatt av allmänt intresse.

40. Bou Gibert mot Spanien (13.5.2003, beslut), von Hannover mot Tyskland No. 1 (24.6.2004 $\S 65)$, Standard Verlags GmbH mot Österrike No. 2 (4.6.2009 § 52) och Hachette Filipacchi Associés (ICI PARIS) mot Frankrike (23.7.2009 § 43).

41. Lingens mot Österrike (8.7.1986 § 42), Unabhängige Initiative Informationsvielfalt mot Österrike (26.2.2002 § 36), Krone Verlag GmbH \& Co. Kg mot Österrike (26.2.2002 § 35), Karhuvaara och Iltalehti mot Finland (16.11.2004 § 40), Iltalehti m.fl. mot Finland $(6.4 .2010 \S 51)$, Saaristo mot Finland (12.10.2010 §§ 59-60) och Flinkkilä mot Finland (6.4.2010§74).

42. Thoma mot Luxemburg (29.3.2001), Nikula mot Finland (21.3.2002), Abeberry mot Frankrike (21.9.2004) samt Pedersen och Baadsgaard mot Danmark (17.12.2004, röst.). För tjänstemännens del åtnjuter t.ex. domare större skydd än åklagare.

43. Krone Verlag GmbH \& Co. Kg mot Österrike (26.2.2002) och Karhuvaara m.fl. mot Finland (16.11.2004).

44. von Hannover mot Tyskland No. I (24.6.2004 § 65), Karhuvaara m.fl. mot Finland (16.11.2004 § 45), Standard Verlags GmbH mot Österrike No. 2 (4.6.2009 § 53) och Axel Springer AG mot Tyskland (7.2.2012 §91).

45. Jfr även Yleisradio mot Finland (8.2.2011, beslut), där EMD instämde med högsta domstolens konstaterande om att det informativa värdet av ett program där det berättades om sexuellt utnyttjande riktat mot barn inte hade nedsatts om objektet för intervjun hade framträtt som oidentifierbar, istället för att uppträda med eget förnamn och ansikte och därigenom avslöja brottsoffrens identitet.

46. EMD:s avgörande påverkades även av att kvinnan fătt ersättning även av andra tidningar. Se avgörandena mot Finland i målen Flinkkilä m.fl., Soila, Tuomela m.fl. och Jokitaipale m.fl. som avgjordes 6.4.2010. 
47. Hachette Filipacchi Associés (ICI PARIS) mot Frankrike (23.7.2009 § 53) och Axel Springer mot Tyskland (7.2.2012 §§92 och 101).

48. Eerikäinen m.fl. mot Finland (10.2.2009). Om skyddet av bild och avsaknaden av kravet på lagföreskrivning Sciacca mot Italien (11.1.2005 §30).

49. Lindon, Otchakovsky-Laurens och July mot Frankrike (22.10.2007, stor avdelning § 59), Radio France m.fl. mot Frankrike (30.4.2004 § 40), Rumyana Ivanova mot Bulgarien (14.2.2008 § 68), Saaristo m.fl. mot Finland (12.10.2010 § 69), Niskasaari m.fl. mot Finland (6.7.2010 § 77) och Ruokanen m.fl. mot Finland (6.4.2010 § 50).

50. T.ex. Maroglou mot Grekland (23.10.2003, beslut) nästan 60000 euro per kränkt person (åtminstone 2 pers.), Bou Gibert mot Spanien (13.5.2003, beslut) ersättning på ca 60000 euro och Independent News and Media och Independent Newspapers Ireland Limited mot Irland (16.6.2005) ersättning på ca 380000 euro. I fallet Pakdemirli mot Turkiet (22.2.2005) ansåg EMD att de skadestånd på ca 60000 euro som klaganden betalat var oproportionerliga, men tillerkände denne »i skälighetens namn« enbart 35000 euro ersättning för all skada.

51. Se även Jersild mot Danmark (23.9.1994 § 35).

52. Flauss 2009 s. 848. Se även kritiken i Voorhoof och Cannie 2010. 